\title{
Sistem Informasi Penilaian Angka Kredit Dosen Berbasis Web (Studi Kasus PAK Online Kopertais Wilayah I DKI Jakarta)
}

\author{
Ahmad Sulhi
}

\begin{abstract}
Abstrak-Penilaian angka kredit dosen untuk kenaikan pangkat jabatan fungsional di Kopertais Wilayah 1 DKI Jakarta selama ini dilakukan dengan cara manual. Cara penilaian konvensional tersebut tentu saja sangat tidak efektif dan efisien. Para dosen yang berada di bawah binaan Kopertais sebanyak 299 yang tersebar pada 58 Perguruan Tinggi Kelembagan Islam Swasata (PTKIS) sangat kesulitan membawa dokumen yang dipersyaratkan serta letak kantor Kopertais yang relatif jauh. Selain itu staf kepegawaian dan assessor juga kesulitan menilai semua dokumen yang seringkali tidak tertata dengan rapih. Pembuatan sistem informasi penilaian angka kredit secara online ini diharapan dapat mengatasi permasalahan tersebut. Metodologi dalam pembangunan perangkat lunak ini menggunakan metode Waterfall dengan bahasa pemerograman PHP dan PostgreSQL sebagai basis data. Sementara framework PHP yang digunakan adalah Laravel. Adapun pengujian perangkat lunak ini menggunakan metode Black Box. Hasil akhir implementasi sistem ini dapat berjalan dengan baik dan sesuai dengan kebutuhan fungsional sistem.
\end{abstract}

Keywords-Penilaiangan Angka Kredit; Waterfall; Web; Laravel; PostgreSQL

\section{PENDAhUluAN}

$\mathrm{D}$ ewasa ini perguruan tinggi di Indonesia cukup banyak telah memanfaatkan teknologi informasi dalam mendukung kegiatan-kegiatannya. Pada umumnya teknologi komputer digunakan untuk mendukung proses-proses administratif, seperti administrasi akademik, keuangan, dan kepegawaian[1]. Pemanfaatan teknologi informasi pada Perguruan Tinggi Kelembagaan Islam Swasta (PTKIS) juga mengalami peningkatan yang signifikan sejak diberlakukannya beberapa kebijakan dalam pemanfaatan teknologi informasi di Kementerian RI[2].

Kopertais DKI Jakarta mempunyai tugas dan fungsi yaitu membantu Direktorat Jenderal Pendidikan Islam Kementerian Agama R.I. dalam melakukan teknis pengawasan, pengendalian mutu, pembinaan, dan pemberdayaan PTKIS dalam bidang kelembagaan, akademik, ketenagaan, sarana, dan prasarana. Saat ini, terdapat 58 PTKIS yang berada dalam binaan Kopertais DKI Jakarta[3]. Salah satu bukti pemanfaatan teknologi informasi di Kopertis DKI Jakarta adalah telah

Received: 24 Juni 2020 ; Revised: 30 Juni 2020 ; Accepted: 1 Juli 2020 diimplementasikannya Sistem Informasi Laporan Beban Kinerja Dosen (BKD) secara online[4].

Berangkat dari keberhasilan penerapan BKD Online di atas, pihak Kopertais DKI Jakarta mengambil kebijakan membangun kembali sistem informasi untuk Penilaian Angka Kredit dosen secara online. Kenaikan Jabatan Fungsional (Jafung) untuk Asisten Ahli, Lektor 200, dan Lektor 300 selama ini memang masih dilakukan dengan cara manual. Sementara untuk jenjang Lektor Kepala dan Guru Besar dilaksanakan di Dirjen Diktis (Kemenag) dan Dirjen Dikti (Kemendikbud) secara online melalui laman http://diktis.kemenag.go.id/pak/.

Dari wawancara yang penulis lakukan dengan beberapa dosen, dan staf Kopertais yang mengurus kenaikan pangkat, serta Kasubag Bina PTKIS Kopertais Wilayah 1 DKI Jakarta, penulis menemukan beberapa permasalahan baik di pihak dosen, staff kepegawaian, maupun pimpinan Kopertais. Permasalahan yang dialami dari pihak dosen antara lain: 1) Prosedur atau alur pengajuan kenaikan pangkat terlalu panjang, mulai dari pengajuan di fakultas, dilanjutkan ke kepagawaian rektorat, kemudian baru ke Kopertais; 2) Berkas sebagai bukti kinerja Tri Dharma yang berbentuk hardcopy cukup banyak dan tebal, sehingga resiko tercecer atau terselip dengan berkas pengajuan dosen lainnya sangat mungkin terjadi, baik di tingkat fakultas, bagian kepegawaian rektorat, maupun Kopertais; 3) Proses penilaian angkat kredit seringkali membutuhkan waktu relatif lama, mengingat tim penilai (Asesor) tersebar dari beberapa PTKIS dan penilaian harus dilakukan di Kopertais; 4) Jarak tempuh dosen dalam mengurus kenaikan pangkat cukup jauh, mulai dari PTKIS masing-masing hingga ke gedung Kopertais Wilayah 1 DKI Jakarta. Belum lagi jika ada perbaikan atau kekurangan berkas sesuai catatan asesor, dosen harus bolak-balik untuk memenuhi kekurangan tersebut.

Sedangkan permasalahan yang dihadapi staf kepegawaian Kopertais antara lain: 1) Penataan berkas pengajuan kenaikan pangkat dosen yang tersebar dari 58 Perguruan Tinggi Kelembagan Islam Swasata (PTKIS) pada setiap priode kenaikan pangkat cukup banyak, sehingga cukup kesulitan dalam pengelolaan berkas tersebut; 2) Staf Kepegawaian Kopertais kesulitan dalam membuat rekap, karena harus menginput semua item kegiatan Tri Dharma ke dalam

A. Sulhi, Program Studi Teknik Informatika, Universitas Islam Negeri Syarif Hidayatullah Jakarta, Indonesia (e-mail: sulhi@uinjkt.ac.id) 
Microsoft Excel untuk setiap pengajuan, sementara SDM yang ada di Kopertais sangat terbatas; 3) Staff kepegawaian Kopertais kesulitan dalam mengetahui jumlah dosen yang sedang atau akan mengajukan kenaikan jabatan akademik. Untuk mengetahui jumlah dosen berdasarkan jabatan akademiknya staff harus melakukan pengecekkan berkas terlebih dahulu.

Sementara permasalahan yang dihadapi oleh Kasubag serta pimpinan Kopertais lainnya adalah sulitnya mengatur ketersediaan waktu bagi asesor yang tersebar dari 58 PTKIS untuk menilai angka kredit dosen dalam waktu yang sudah ditetapakan. Selain karena kesibukan dan kewajiban asesor pada masing-masing PTKIS, juga karena proses penialaian harus dilaksanakan di gedung Kopertais.

Dari hasil indentifikasi masalah tersebut mendorong penulis untuk membuat sebuah sistem penilaian angka kredit berbasis web (online). Sistem informasi ini diharapkan dapat mempermudah dalam proses kenaikan jabatan fungsional dosen dan sekaligus dapat menampilkan dashboard guna mempermudah pimpinan untuk mengetahui dan memantau perkembangan mengenai peta kenaikan jabatan fungsional akademik dosen PTKIS di bawah binaan Kopertais Wilayah 1 DKI Jakarta secara cepat, efektif, real time dan dapat diakses dimana pun.

\section{KAJIAN PENELITIAN}

\section{A. Penelitian Sebelumnya}

Ada beberapa penelitian serupa yang telah dilakukan sebelumnya di antaranya adalah penelitian yang dilakukan oleh Endang Lestari (2016), dengan judul Pengembangan Sistem Penilaian Angka Kredit untuk Kenaikan Jabatan Akademik Dosen pada Jurusan Sistem Informasi Fakultas Ilmu Komputer Universitas Sriwijaya. Sistem ini mengikuti pedoman operasional penilaian angka kredit kenaikan pangkat/jabatan akademik dosen oktober 2014 dengan menggunakan metode FAST (Framework for the Application of System Techniques)[5]. Penggunaan sistem informasi ini hanya pada tingkat jurusan, yaitu Jurusan Sistem Informasi pada Fakultas Ilmu Komputer, Universitas Sriwijaya. Keluaran yang dihasilkan berupa rekap hasil penilaian angka kredit yang kemudian diajukan ke Ketua Jurusan untuk disetujui sebagai bahan pengajuan kenaikan pangkat ke universitas.

Penelitian lainnya yang dilakukan oleh Brigida Arie Minartiningtyas (2018), dengan judul Rancang Bangun Sistem Informasi Perhitungan Angka Kredit Dosen STMIK STIKOM Indonesia[6]. Metode pengembangan sistem menggunakan Waterfall, sedikit berbeda dengan metode pengembangan sistem Rapid Application Development (RAD) yang akan dilakukan pada penelitian ini. Perbedaan lainnya pada pengembangan sistem ini terletak pada fitur penilaian yang dilakukan oleh assessor, di mana assessor akan memverifikasi, memvalidasi serta menilai bukti dokumen yang diunggah oleh dosen.

Penelitian berikutnya dilakukan oleh Andre Agasi (2018) dengan judul Perancangan Sistem Informasi Kenaikan Jabatan Fungsional Dosen dengan Framework Laravel Bebrbasis Web[7]. Tidak dijelaskan metodologi yang digunakan dalam pengembangan sistem, selain penggunaan Unified Modeling Language (UML) untuk design sistem.
Sama seperti penelitian yang dilakukan oleh Endang Lestari (2016), aplikasi ini digunakan pada level jurusan, yaitu Jurusan Elektronika Fakultas Teknik Universitas Negeri Padang. Keluaran dari aplikasi ini bukan berupa Surat Kenaikan Jabatan Fungsional, tetapi merupakan rekap hasil perhitungan angka kredit dosen.

\section{B. Penilaian Angka Kredit Dosen}

Sistem penilaian angka kredit pada aplikasi ini sepenuhnya mengacu kepada Pedoman Operasional Penilaian Angka Kredit Kredit Kenaikan Jabatan Akademik/Pangkat Dosen yang dikeluarkan oleh Direktorat Jenderal Sumber Daya Iptek dan Dikti Kementerian Riset, Teknologi dan Pendidikan Tinggi Tahun 2019. Pedoman tersebut disusun berdasarkan Peraturan Menteri Pendidikan dan Kebudayaan Republik Indonesia Nomor 92 Tahun 2014 tentang Petunjuk Teknis Pelaksanaan Penilaian Angka Kredit Jabatan Fungsional Dosen dan Angka Kreditnya.

Dalam pedoman operasional tersebut disebutkan bahwa komponen penilaian dalam jabatan akademik dosen terdiri dari dua unsur yaitu, (i) unsur utama yang meliputi pendidikan (pengajaran), penelitian, dan pengabdian kepada masyarakat dan (ii) unsur penunjang yang merupakan kegiatan pendukung pelaksanaan tugas pokok dosen. Jumlah angka kredit kumulatif minimal yang harus dipenuhi oleh setiap dosen untuk dapat diangkat dalam jabatan akademik paling sedikit dibutuhkan angka kredit 90\% (sembilan puluh persen) dari unsur utama, serta unsur penunjang paling banyak dibutuhkan angka kredit $10 \%$ (sepuluh persen) atau boleh tidak ada[8].

Berikut ini distribusi unsur utama dan unsur penunjang dalam setiap usul kenaikan jabatan akademik sebagaimana disajikan pada Tabel 1 di bawah ini.

Tabel 1.

Angka Kredit Kumulatif Unsur Utama dan Unsur Penunjang

\begin{tabular}{|c|c|c|c|c|c|}
\hline \multirow[b]{2}{*}{ No } & \multirow[b]{2}{*}{ Jabatan } & \multicolumn{3}{|c|}{ Unsur Utama } & \multirow[b]{2}{*}{$\begin{array}{c}\text { Unsur } \\
\text { Penunjang }\end{array}$} \\
\hline & & $\begin{array}{c}\text { Pelaksanaan } \\
\text { Pendidikan }\end{array}$ & $\begin{array}{c}\text { Pelaksanaan } \\
\text { Penelitian }\end{array}$ & $\begin{array}{l}\text { Pengabdian } \\
\text { Masyarakat }\end{array}$ & \\
\hline 1 & Asisten Ahli & $\geq 55 \%$ & $\geq 25 \%$ & $\leq 10 \%$ & $\leq 10 \%$ \\
\hline 2 & Lektor & $\geq 45 \%$ & $\geq 35 \%$ & $\leq 10 \%$ & $\leq 10 \%$ \\
\hline 3 & Lektor Kepala & $\geq 40 \%$ & $\geq 40 \%$ & $\leq 10 \%$ & $\leq 10 \%$ \\
\hline 4 & Professor & $\geq 35 \%$ & $\geq 45 \%$ & $\leq 10 \%$ & $\leq 10 \%$ \\
\hline
\end{tabular}

\section{MEtOdE PENELITIAN}

Metode penelitian dalam pengembangan perangkat lunak ini menggunakan model Waterfall. Model ini sering disebut juga model Klasik (Classic Life Cycle) atau model Sekuensial Linier (Linear Sequential) yang merupakan paradigma model pengembangan perangkat lunak paling tua, dan paling banyak dipakai.

Model Waterfall mengusulkan sebuah pendekatan pengembangan perangkat lunak yang sistematik dan sekunsial dengan enam tahapan, yaitu rekayasa dan pemodelan sistem/informasi, analisis kebutuhan perangkat lunak, disain atau perancangan, pembuatan kode, pengujian, dan pemeliharaan[9]. 


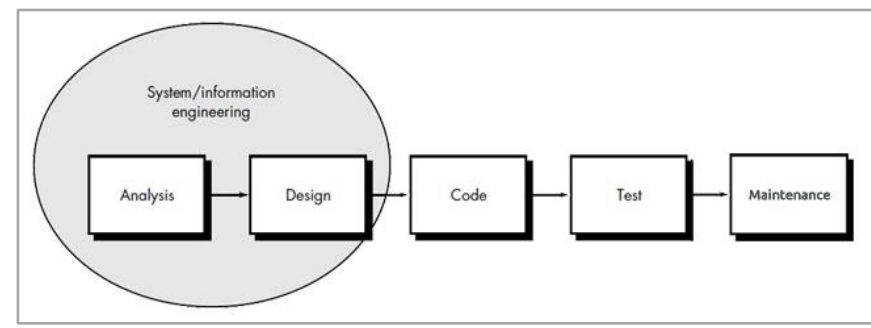

Gambar 1. Model Waterfall

Berikut penjelasan singkat tahapan pengembangan perangkat lunak dengan model Waterfall:

1) Rekayasa dan Pemodelan Sistem/Informasi (System/ Information Engineering and Modeling)

Langkah pertama ini dimulai dengan membangun keseluruhan elemen sistem dan memilah bagian-bagian mana yang akan dijadikan bahan pengembangan perangkat lunak, dengan memperhatikan hubungannya dengan hardware, pengguna, dan database. Mengingat sistem informasi yang akan dibangun berbasis web, maka ketersediaan server dan bandwidth internet merupakan persyaratan utama yang harus disiapkan. Dedicated server yang disiapkan pihak Kopertais untuk menjalankan sistem infomasi ini diletakan pada Data Center Pustipanda UIN Syarif Hidayatullah Jakarta.

2) Analisis Kebutuhan Perangkat Lunak (Software Requirements Analysis)

Mengumpulkan kebutuhan secara lengkap kemudian dianalisis dan didefinisikan kebutuhan yang harus dipenuhi dalam perancangan perangkat lunak sesuai dengan kebutuhan Kopertais. Dengan alasan stabilitas dan performa yang baik serta efisiensi, operating system yang digunakan adalah Linux dengan distro Ubuntu 18.04 LTS. Sementara database menggunakan PosgreSQL versi 10.2.

3) Desain (Software Design)

Pada proses desain, dilakukan penerjemahan syarat kebutuhan sebuah perancangan perangkat lunak yang dapat diperkirakan sebelum dibuatnya proses pengkodean (coding). Proses ini berfokus pada struktur data, arsitektur perangkat lunak, representasi interface, dan detail algoritma prosedural. Adapun pemodelan yang digunakan dalam pengembangan perangkat lunak ini menggunakan Unified Modelling Language (UML). UML adalah salah satu alat bantu yang sangat handal di dunia pengembangan sistem yang berorientasi objek[10]. Dalam pemodelan menggunakan UML, terdapat beberapa diagram yang merepresentasikan model sistem, di antaranya adalah Use Case Diagram, Activity Diagram, Class Diagram dan Deployment Diagram.

4) Pengkodean (Code Generation)

Pengkodean merupakan proses menterjemahkan perancangan desain ke bentuk yang dapat dimengerti oleh mesin, dengan menggunakan bahasa pemrograman. Adapun IDE (Integrated Development Environment) yang digunakan dalam pengkodean perangkat lunak ini ini adalah Sublime Text 3.

5) Pengujian (Testing)

Setelah Proses Pengkodean selesai, dilanjutkan dengan proses pengujian untuk memeriksa segala kemungkinan terjadinya kesalahan dan memeriksa apakah hasil dari pengembangan tersebut sesuai dengan hasil yang diinginkan. Metode yang digunakan dalam pengujian perangkat lunak ini menggunakan Black Box Testing atau yang sering dikenal dengan sebutan pengujian fungsional. Black Box Testing merupakan metode pengujian perangkat lunak yang digunakan untuk menguji perangkat lunak tanpa mengetahui struktur internal kode atau program. Dalam pengujian ini, tester menyadari apa yang harus dilakukan oleh program tetapi tidak memiliki pengetahuan tentang bagaimana melakukannya.[11]

6) Pemeliharaan (Maintenance/Support)

Proses pemeliharaan merupakan bagian paling akhir dari siklus pengembangan dan dilakukan setelah perangkat lunak dipergunakan. Pada tahun pertama, pemeliharaan perangkat lunak menjadi tanggung jawab pengembang, pemeliharaan selanjutnya diserahkan kepada pihak Kopertais selaku pemilik perangkat lunak ini.

\section{HASIL DAN PEMBAHASAN}

\section{A. Analisis Sistem Berjalan}

Menganalisis sistem yang sedang berjalan merupakan langkah penting yang harus dilaksanakan sebelum memberikan gambaran sistem yang akan diusulkan. Tanpa ada pemahaman yang baik terhadap sistem berjalan, maka sistem yang akan diusulkan nanti tentu tidak akan menghasilkan output yang diinginkan dan dapat mencapai tujuan yang direncanakan.

Sebelum menganalisis sistem berjalan yang ada di Kopertais Wilayah 1 DKI Jakarta, berikut ini tabel perbandingan berdasarkan studi literatur mengenai sistem informasi penilaian angka kredit dosen sebelumnya.

Tabel 2.

Sistem Informasi Penilaian Angka Kredit Sebelumnya

\begin{tabular}{|c|c|c|c|}
\hline $\mathrm{No}$ & Peneliti & Kelebihan & Kekurangan \\
\hline 1 & $\begin{array}{l}\text { Endang } \\
\text { Lestari[5] }\end{array}$ & $\begin{array}{l}\text { - Menghitung angka } \\
\text { kredit dosen secara } \\
\text { otomatis berdasarkan } \\
\text { PO Penilaian Angka } \\
\text { Kredit Tahun } 2014 \\
\text { - Dashboard untuk } \\
\text { monitoring perkem- } \\
\text { bangan data kenaikan } \\
\text { jabatan dosen, dan } \\
\text { memprediksi kondisi } \\
\text { yang akan datang } \\
\text { - Berbasis web } \\
\text { - Mengunggah bukti } \\
\text { fisik dokumen }\end{array}$ & $\begin{array}{l}\text { - } \text { Berlaku di tingkat } \\
\text { Fakultas (Fakultas } \\
\text { Ilmu Komputer) } \\
\text { Universitas Sriwijaya) } \\
\text { - Output berupa rekap } \\
\text { nilai angka kredit, } \\
\text { apakah nilai kredit } \\
\text { sudah cukup atau } \\
\text { belum untuk } \\
\text { mengajukan kenaikan } \\
\text { jabatan fungsional } \\
\text { dosen. } \\
\text { Tidak menghitung } \\
\text { lompat jabatan dan } \\
\text { kelebihan kum secara } \\
\text { lebih detail. }\end{array}$ \\
\hline 2 & $\begin{array}{l}\text { Brigida } \\
\text { Arie } \\
\text { Minartining } \\
\text { tyas[6] }\end{array}$ & $\begin{array}{l}\text { Menghitung angka } \\
\text { kredit dosen secara } \\
\text { otomatis berdasarkan } \\
\text { PO Penilaian Angka }\end{array}$ & $\begin{array}{l}\text { - Tidak ada proses } \\
\text { penilaian oleh asesor } \\
\text { - Sistem belum dapat } \\
\text { menginformasikan }\end{array}$ \\
\hline
\end{tabular}




\begin{tabular}{|c|c|c|c|}
\hline & & $\begin{array}{l}\text { Kredit Tahun } 2014 \\
\text { - } \text { Berbasis Web } \\
\text { - Mengunggah bukti } \\
\text { fisik dokumen }\end{array}$ & $\begin{array}{l}\text { kekurangan poin } \\
\text { dosen ada pada } \\
\text { komponen yang } \\
\text { mana. }\end{array}$ \\
\hline 3 & $\begin{array}{l}\text { Andre } \\
\text { Agasi[7] }\end{array}$ & $\begin{array}{l}\text { Menghitung angka } \\
\text { kredit dosen secara } \\
\text { otomatis berdasarkan } \\
\text { PO Penilaian Angka } \\
\text { Kredit Tahun } 2014 \\
\text { - Berbasis Web }\end{array}$ & $\begin{array}{l}\text { Berlaku di tingkat } \\
\text { Fakultas (Jurusan } \\
\text { Teknik Elektronika } \\
\text { dan Fakultas Teknik } \\
\text { Universitas Negeri } \\
\text { Padang) } \\
\text { - Output berupa rekap } \\
\text { nilai angka kredit, } \\
\text { apakah nilai kredit } \\
\text { sudah cukup atau } \\
\text { belum untuk } \\
\text { mengajukan kenaikan } \\
\text { jabatan fungsional. } \\
\end{array}$ \\
\hline
\end{tabular}

Berdasarkan analisis sistem berjalan sebelumnya, seperti dijelaskan pada Tabel 2 di atas, sistem informasi tersebut belum bisa menjawab permasalahan yang ada di Kopertais Wilayah 1 DKI Jakarta. Sistem informasi yang dibutuhkan bukan hanya untuk menghitung perolehan angka kredit oleh dosen, tetapi mengelola semua proses kenaikan jabatan, mulai dari input item kegiatan Tri Dharma dosen, mengunggah bukti dokumen, proses penilaian oleh assesor, hingga diterbitkannya SK Kenaikan Fungsional Akademik dan Penetapan Angka Kredit (PAK) dosen.

Gambaran prosedur pengajuan kenaikan jabatan fungsional dosen di Kopertais secara konvensional (manual) di Kopertais Wilayah 1 DKI Jakarta dapat dimodelakan seperti Gambar 2 di bawah ini.

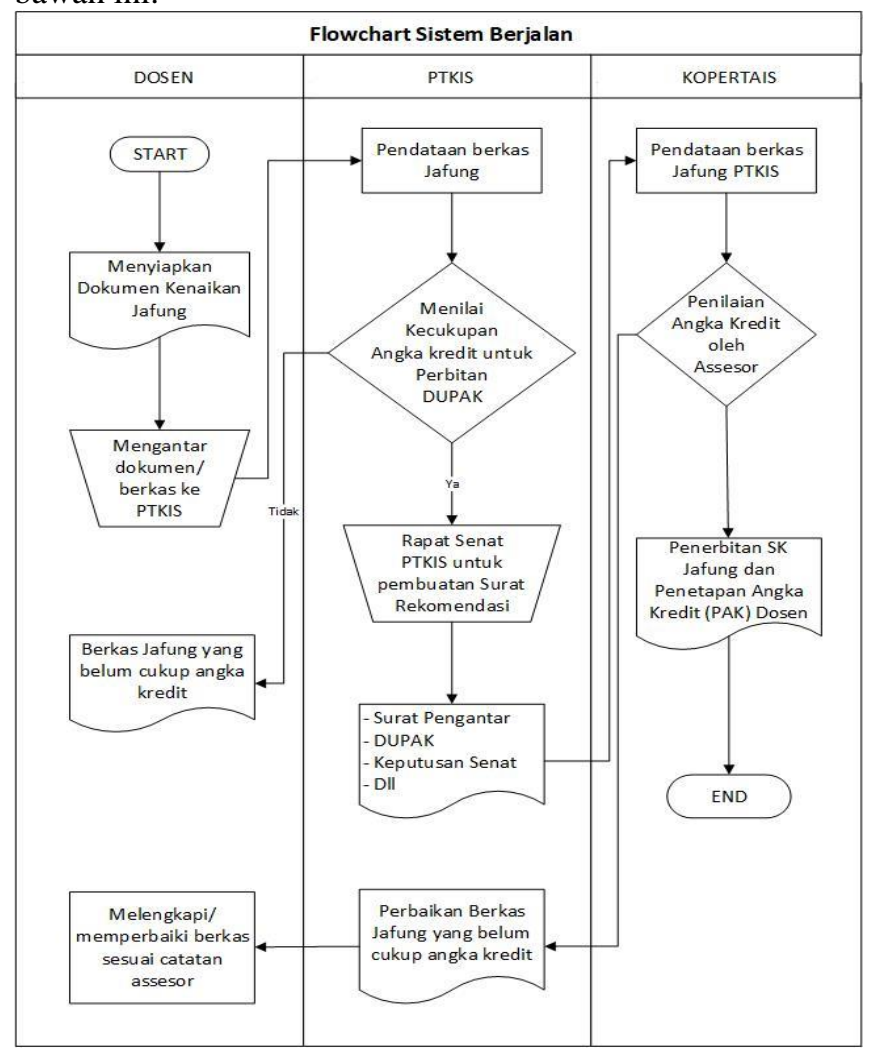

Gambar 2. Sistem Berjalan Pengajuan Jafung

Berikut ini adalah penjelasan dari gambar 2 mengenai sistem yang berjalan saat ini di Kopertais Wilayah 1 DKI Jakarta :
1) Dosen menyiapkan dokumen-dokumen untuk kenaikan pangkat jabatan fungsional;

2) Jika dokumen sudah lengkap, mulai dari bidang pengajaran, penelitian, pengabdian, dan penunjang lainnya, kemudian dosen membawa dokumen tersebut ke Fakultas PTKIS;

3) Staf kepegawaian fakultas akan mendata untuk dibuat Daftar Usul Penetapan Angka Kredit (DUPAK);

4) Menginput data tersebut ke DUPAK dan menilai kecukupan angka kredit masing-masing bidang. Jika angka kredit belum cukup, dokumen dikembalikan ke dosen pengusul. Jika memenuhi akan dibawa ke Rapat Senat Fakultas;

5) Setelah senat menyetujui, maka dibuatlah Surat Pengantar kenaikan Jafung, DUPAK, Surat Keputusan Senat, dan surat persyaratan lainnya untuk diajukan ke Kopertais;

6) Langkah selanjutnya adalah penilaian oleh asessor. Jika hasil penilaian yang dilakukan oleh assessor memenuhi angka kredit, maka dibuatlah SK Jafung serta Penetapan Angka Kredit Dosen. Jika tidak memenuhi atau terdapat kekurangan angka kredit akan dikembalikan ke dosen yang bersangkutan untuk selanjutnya diperbaiki atau dilengkapi sesuai catatan assessor;

7) Selesai.

\section{B. Analisis Sistem Usulan}

Berdasarkan permasalahan dan kelemahan dari analisa sistem yang sedang berjalan, maka diusulkan perancangan Sistem Informasi Penetapan Angka Kredit Dosen berbasis web secara online. Sistem yang dirancang nantinya akan menjadi solusi serta mendukung proses penetapan Angka Kredit Dosen yang diharapkan lebih efektif dan efisien. Perancangan sistem usulan akan memberikan gambaran dan penjelasan secara detail mengenai bentuk dan rancangan kerja dari sistem usulan dalam memenuhi kebutuhan operasional organisasi.

Agar perancangan Sistem Informasi Penetapan Angka Kredit Dosen Berbasis Web pada Kopertais Wilayah 1 DKI Jakarta ini dapat dipahami dengan baik dan mudah, maka digunakan pemodelan sistem menggunakan pendekatan berorientasi objek yaitu dengan menggunakan diagram Unifield Modeling Language (UML).

Adapun diagram UML yang akan digunakan pada perancangan sistem informasi ini, yaitu Use case Digaram.

\section{1) Use Case Diagram}

Salah satu teknik yang banyak digunakan untuk membuat berbagai jenis pemodelan sistem informasi adalah use case. Teknik Ini digunakan untuk menggambarkan perilaku sistem, seperti respon sebuah permintaan atau stimulus dari luar sistem. Sebuah use case menggambarkan "siapa" yang dapat melakukan "apa" dengan sistem yang dimaksud. Teknik use case digunakan untuk menangkap perilaku sistem dengan menentukan fungsionalitas berdasarkan berbagai skenario yang mungkin diperlukan oleh sebuah sistem.[12]

Tujuan use case dibuat pada dasarnya yaitu untuk mengumpulkan kebutuhan dari sebuah sistem, baik itu karena pengaruh internal maupun pengaruh eksternal. Selain itu, use case juga digunakan untuk menggambarkan 
analisis kebutuhan dari sistem dan interaksi daintara para actor [13].

Adapun use case diagram yang diusulkan seperti terlihat pada gambar di bawah ini.

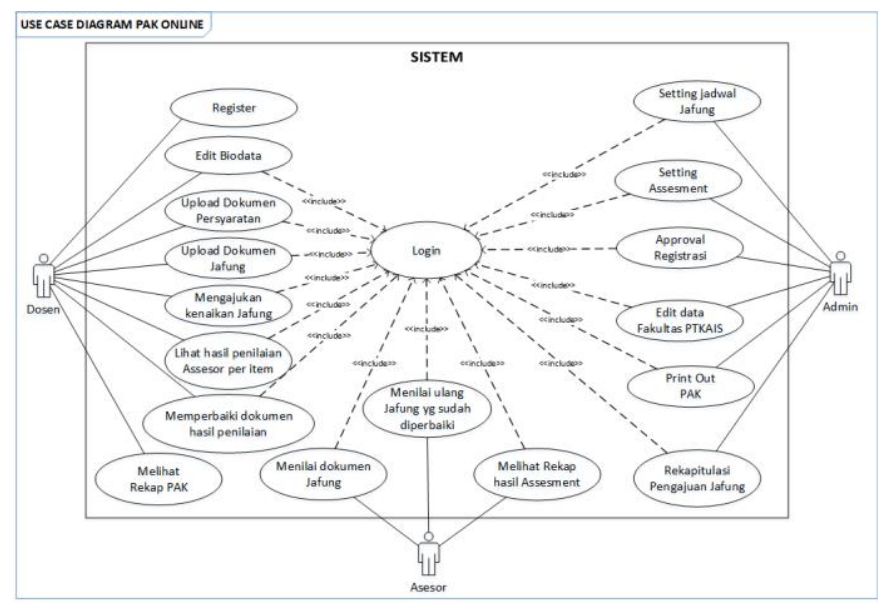

Gambar 3. Use Case Diagram Sistem Usulan

Dari gambar 3 di atas terlihat terdapat tiga aktor, yaitu dosen, assesor dan admin. Deskripsi singkat ketiga aktor tersebut dijelaskan pada Tabel 3 berikut:

Tabel 3.

Aktor yang Terlibat dalam Sistem

\begin{tabular}{|c|c|c|}
\hline $\mathrm{No}$ & Aktor & Keterangan \\
\hline 1 & Dosen & $\begin{array}{l}\text { Dosen sebelum melakukan teransaksi diwajibkan } \\
\text { terlebih dahulu melakukan pendaftaran. Selan-jutnya } \\
\text { Admin akan memverifikasi data tersebut, jika valid } \\
\text { admin meng-approve dan sistem mengirim notifikasi } \\
\text { melalui email bahwa pendaftaran tersebut berhasil. }\end{array}$ \\
\hline 2 & Assesor & $\begin{array}{l}\text { Tim Penilai (Assesor) mempunyai hak dan } \\
\text { wewenang untuk mengakses penilaian angka kredit } \\
\text { dosen pada sistem. Assesor tidak perlu register } \\
\text { seperti dosen. Pembuatan akun Assesor dibuat oleh } \\
\text { Admin. }\end{array}$ \\
\hline 3 & Admin & $\begin{array}{l}\text { Admin mempunyai hak dan wewenang untuk } \\
\text { mengakses segala akses sistem yang ada pada } \\
\text { Sistem. Sama halnya dengan Assesor, akun Admin } \\
\text { tidak perlu register, karena username dan password } \\
\text { Admin dibuat oleh sistem. }\end{array}$ \\
\hline
\end{tabular}

2) Class Diagram

Class Diagram adalah model statis yang menggambarkan struktur dan deskripsi class serta hubungannya antara class. Class diagram mirip dengan Entity Relationalship Diagram (ERD) pada perancangan database, bedanya pada ERD tidak terdapat operasi atau methode tapi hanya atribut. Class terdiri dari nama kelas, atribut dan operasi/methode. Berdasarkan rancangan class diagram, dibuatlah schema database sistem yang diusulkan seperti yang terlihat pada Gambar 4 di bawah ini:

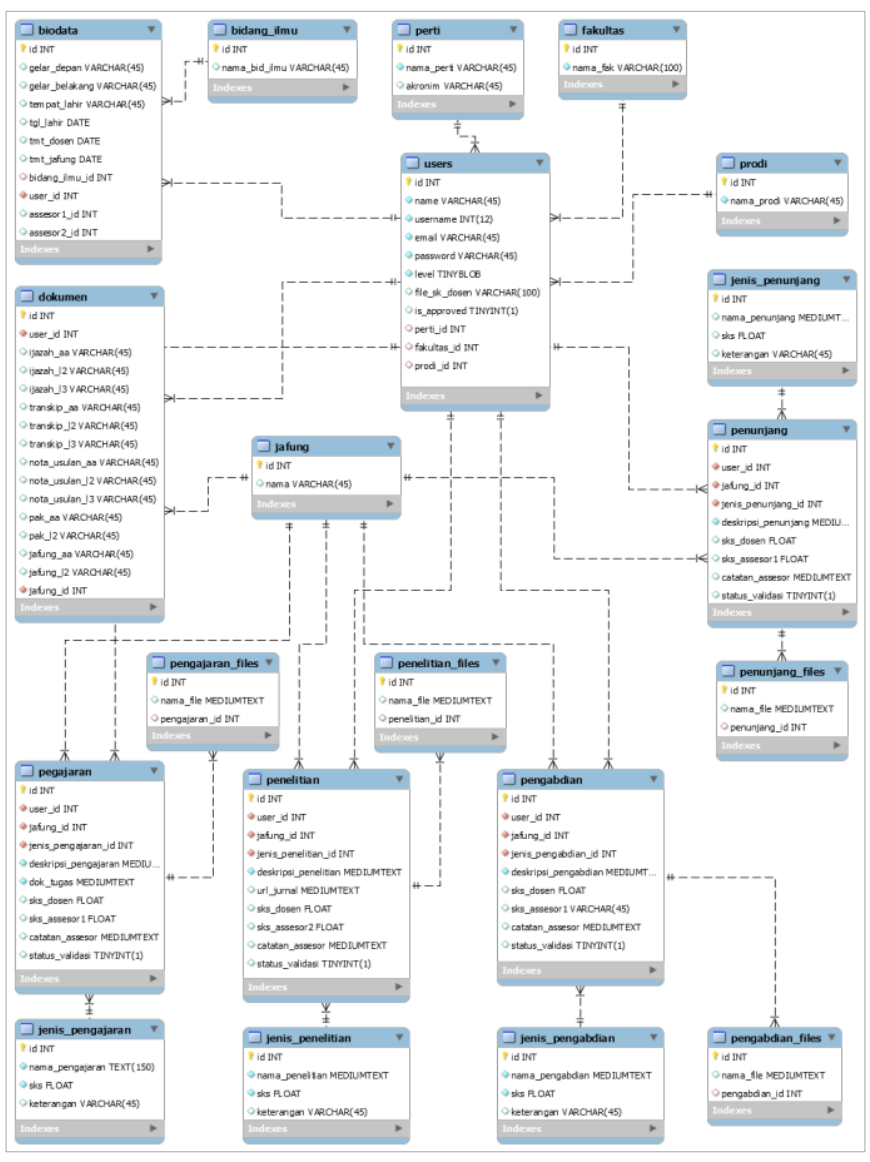

\section{Gambar 4. Schema Database PAK Online}

\section{Kode Program (Code)}

Setelah selesai tahap desain berupa pemodelan sistem yang diusulkan, tahap selanjutnya adalah tahap pembuatan kode program. Adapun bahasa pemerograman yang digunakan adalah PHP 7.4 dengan framework Laravel.

Laravel adalah salah satu Framework PHP yang paling populer dan paling banyak digunakan di seluruh dunia dalam membangun aplikasi web mulai dari proyek kecil hingga besar. Framework ini banyak digunakan oleh Web Developer karena kinerja, fitur, dan skalabilitas nya[14].

Framework ini mengikuti struktur MVC (Model, View, Controller), MVC adalah sebuah metode aplikasi dengan memisahkan data dari tampilan berdasarkan komponenkomponen aplikasi, seperti : manipulasi data, controller, dan user interface.

Sistem yang diusulkan ini diharapkan dapat menjawab permasalahan yang ditemukan ketika proses pengajuan kenaikan jabatan fungsional akademik dosen di Kopertais Wilayah 1 DKI Jakarta. Dosen tidak perlu repot membawa bukti dokumen ke Kopertais. Assesor lebih mudah memberi penilaian angka kredit dosen, baik dari segi waktu dan jarak. Dosen dan assesor bisa melakukan interaksi terkait kekurangan atau perbaikan dokumen. Untuk alasan privasi asesor, interaksi tersebut dosen tidak mengetahui siapa nama assesornya. Dosen hanya mengetahui catatan assesor pada dashboard dosen, yaitu pada setiap item kegiatan dosen yang dilaporkan. 
Berikut ini beberapa tampilan (screen shoot) dari Sistem Informasi PAK Online :

\section{Halaman Utama}

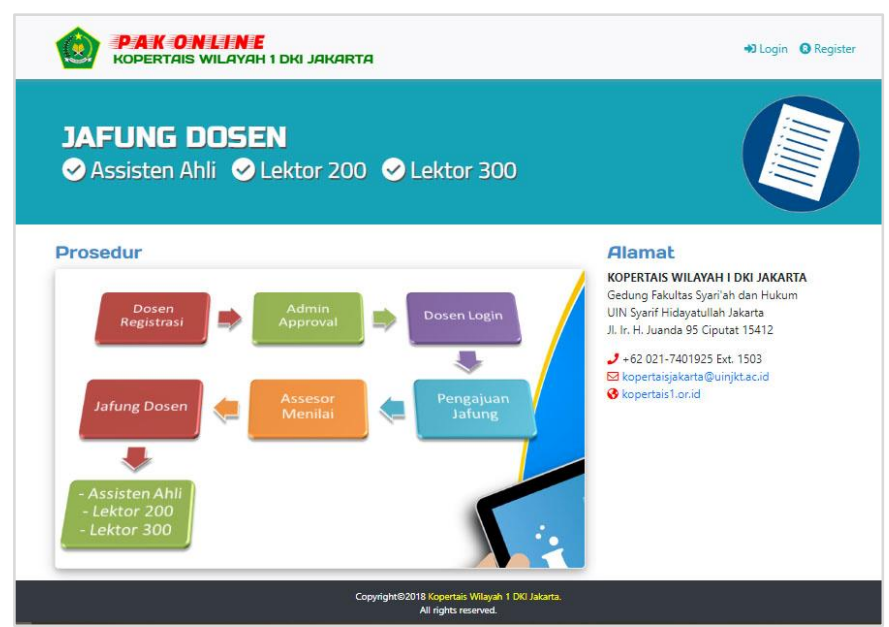

Gambar 5. Homepage

Halaman utama (Homepage) berisi informasi secara umum dari PAK Online, antara lain mengenai prosedur mengajukan jafung, jenis jafung yang dapat diajukan, menu pendaftaran, dan login. Penempatan Prosedur pada halaman utama dimaksudkan agar dosen memahami terlebih dahulu tentang alur untuk pengajuan kenaikan jabatan fungsional dosen.

\section{Halaman Login}

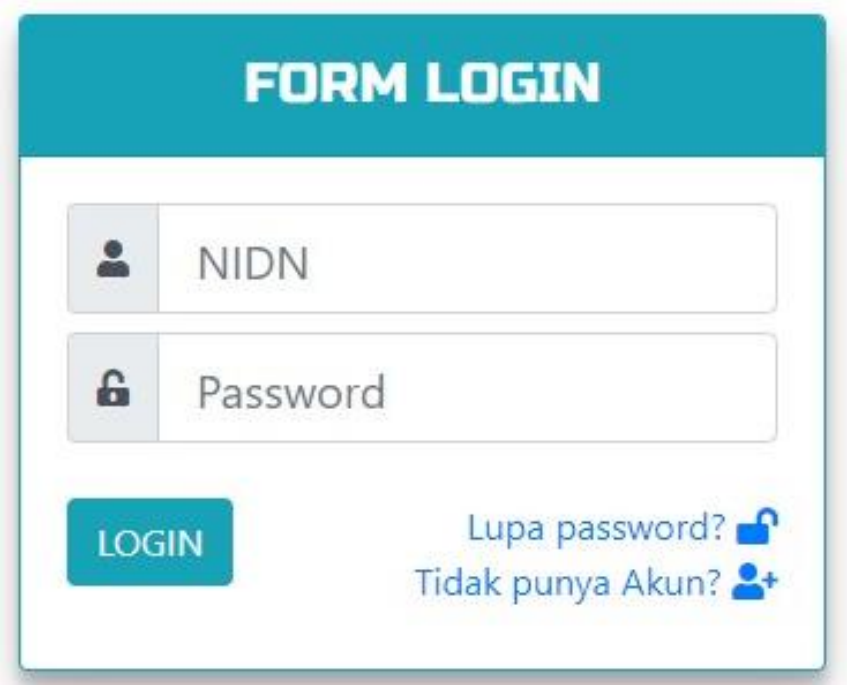

\section{Gambar 6. Halaman Login}

PAK Online menggunakan sistem login dengan autentikasi multi-level dan multi-user. Sistem multi-user adalah sistem operasi yang memungkinkan pengguna lebih dari satu dalam mengakses sistem komputer dalam waktu yang bersamaan Sementara pengertian autentikasi multi-level adalah user dengan level berbeda menggunakan form login yang sama. Setelah login nantinya user akan diarahkan ke hak aksesnya masing-masing.

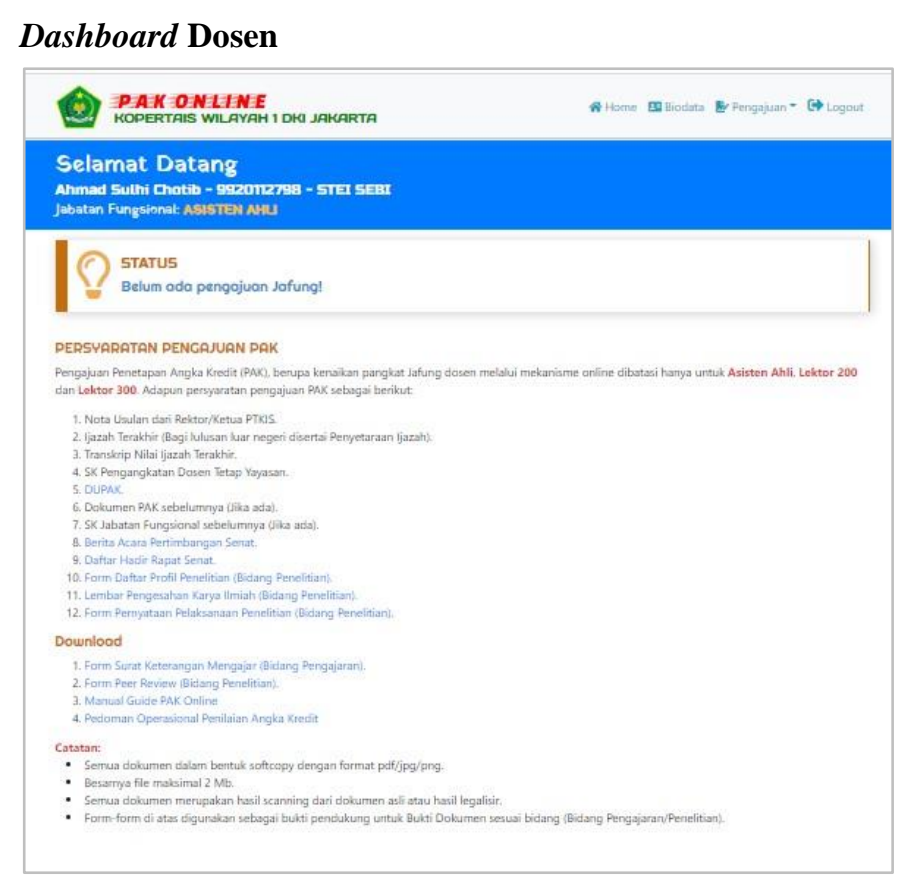

\section{Gambar 7. Dashboard Dosen}

Ketika user dengan level dosen berhasil login, selanjutnya sistem akan mengarahkan user tersebut ke halaman default yaitu halaman dashboard dosen. Dashboard dosen berisi deskripsi singkat data dosen, status pengajuan, dan persyaratan pengajuan jafung.

\section{Pengajuan Jafung}

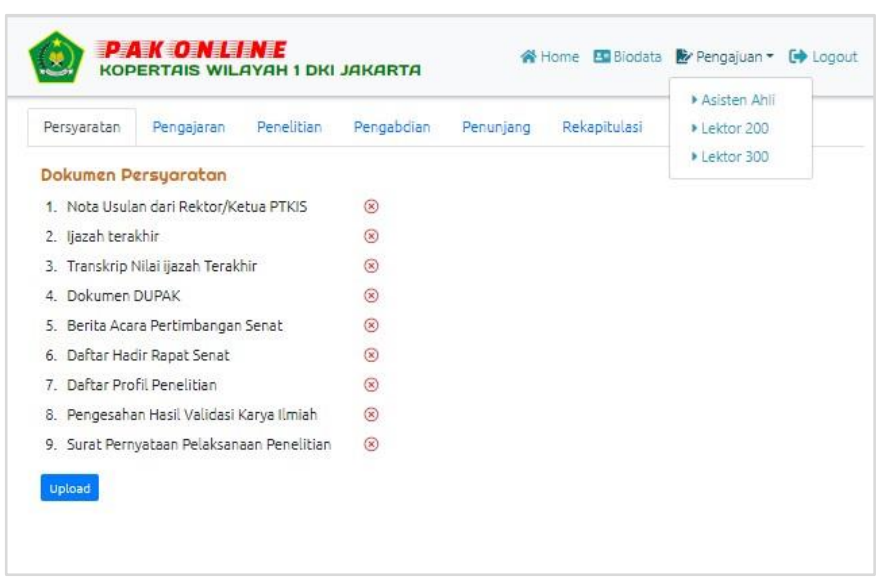

Gambar 8. Upload persyaratan untuk Assisten Ahli

Sistem ini hanya melayani kenaikan jafung untuk Asisten Ahli, Lektor 200, dan Lektor 300. Untuk Lektor Kepala dan Guru Besar, kenaikan Jafung diproses melalui sistem yang ada di Kemenag. Sebelum mengisi laporan Tri Dharma (Pengajaran, Penelitian, Pengabdian, dan Penunjang), dosen terlebih dahulu harus mengupload persyaratan. Dokumen yang diupload berbeda pada setiap levelnya. 


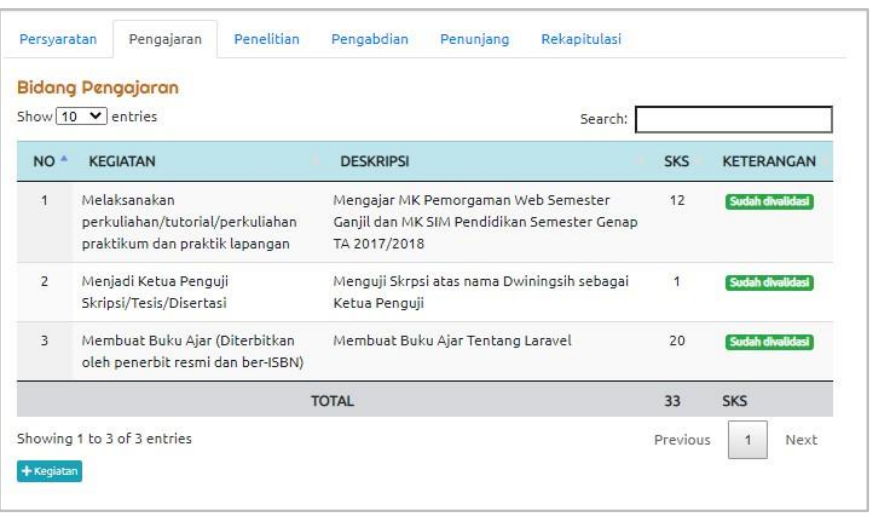

Gambar 9. Bidang Pengajaran

Pada kolom Kegiatan berisi daftar kegiatan sebagai unsur utama pendidikan dan pelaksanaan pendidikan, lengkap dengan bukti kegiatan yang harus diunggah serta angka kredit yang diperoleh per item kegiatan, sebagaimana yang telah dirinci pada Pedoman Operasional Penilaian Angka Kredit Kenaikan Jabatan Akademik/Pangkat Dosen, Tabel 2. Komponen Pendidikan, Pelaksanaan Pendidikan, dan Angka Kredit[8].

Pada kolom Deskripsi, dosen menjelaskan secara singkat tentang item kegiatan yang dilaporkan. Kolom SKS memuat angka kredit yang diberikan oleh assessor, setelah dilakukan verifikasi dan validasi oleh asessor.

Sementara kolom Keterangan berisi menu icon untuk mengedit atau memperbaiki item kegiatan, catatan Assesor dam status validasi. Jika sudah divalidasi, dosen tidak bisa mengedit atau memperbaiki item kegiatan.

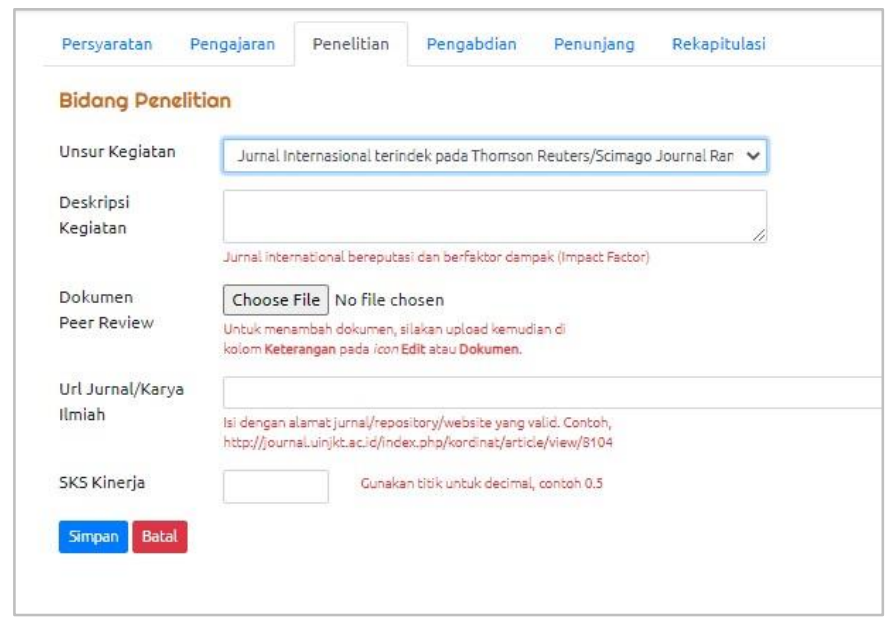

Gambar 10. Melaporkan Item Bidang Penelitian

Seperti halnya pada bidang Pengajaran, unsur kegiatan pada Bidang Penelitian sudah ditentukan item-itemnya. Setelah memilih unsur kegiatan, dosen mengisi kolom Deskripsi Kegiatan, upload dokumen Peer Review, alamat laman karya ilmiah, dan mengisi angka kredit pada kolom SKS Kinerja. Mengunggah dokemen peer review dan mencantumkan tautan bukti kinerja sifatnya wajib. Sistem akan menolak jika dokumen dan tautan link tidak diunggah/diinput.

Untuk kolom SKS, dosen akan mengisi sendiri nilainya berdasarkan ketentuan yang ada pada Pedoman Angka Kredit[8]. SKS tersebut akan diverifikasi dan dinilai ulang oleh asesor. Sistem akan menghitung sesuai dengan nilai yang diberikan oleh asesor, bukan nilai yang diinput oleh dosen.

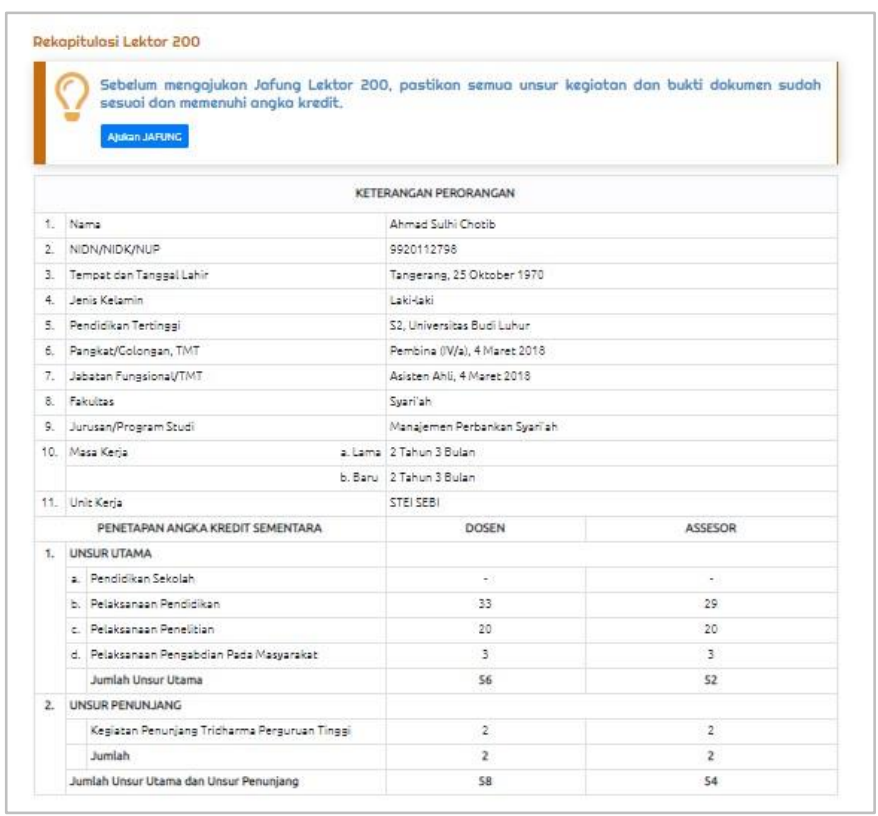

Gambar 11. Rekap Nilai Angka Kredit

Selain melihat rekapulasi nilai angka kredit yang diperoleh oleh penilai (Asesor), dosen juga dapat memonitor dan memperbaiki dokumen sesuai catatan dari asesor pada setiap bidang dan item laporan. Setelah assesor selesai menilai, dosen akan mendapatkan notifikasi melalui e-mail, bahwa dokumen telah selesai dinilai.

\section{Dashboard Asesor}

Setelah assesor berhasil login, sistem akan mengarahkan assesor ke Daftar Assesment (Gambar 12). Untuk menilai dengan cara mengklik link nama dosen pada daftar assesment.

\begin{tabular}{|c|c|c|c|c|c|c|}
\hline (3) & \multicolumn{3}{|c|}{$\begin{array}{l}\text { PAK A ONLINE } \\
\text { KOPERTAIS WILAYAH I DKI JAKARTA }\end{array}$} & \multicolumn{3}{|c|}{ - Prof. Dr. H. Ahmad Thib Raya, M.A. $\leftrightarrow$ Logout } \\
\hline \multicolumn{7}{|c|}{ DAFTAR ASSESMENT } \\
\hline \multicolumn{4}{|c|}{ Show $10 \sim$ entries } & \multicolumn{3}{|l|}{ Search: [ } \\
\hline NO ${ }^{*}$ & $\begin{array}{l}\text { NAMA } \\
\text { LENGKAP }\end{array}$ & NIDN & PROGRAM STUDI & PERGURUAN TINGGI & PENC & AUUAN \\
\hline 1 & $\begin{array}{l}\text { Moh Khoirul } \\
\text { Anam }\end{array}$ & 0317058201 & Zakat dan Wakaf & FAI Universitas Muhammadiyah Jakarta & Lektor & 200 \\
\hline 2 & SATIBI & 2106088805 & $\begin{array}{l}\text { Pendidikan Bahasa } \\
\text { Arab }\end{array}$ & STAI Nurul Iman Bogor & Asiste & Ahli \\
\hline 3 & Mufrodi & 0424048902 & $\begin{array}{l}\text { Pendidikan Bahasa } \\
\text { Arab }\end{array}$ & $\begin{array}{l}\text { FAI Universitas Muhammadiyah } \\
\text { Tangerang }\end{array}$ & Asister & Ahli \\
\hline Showing 1 & 1 to 3 of 3 entrit & & & Previous & 1 & Next \\
\hline
\end{tabular}

Gambar 12. Daftar Assesment 


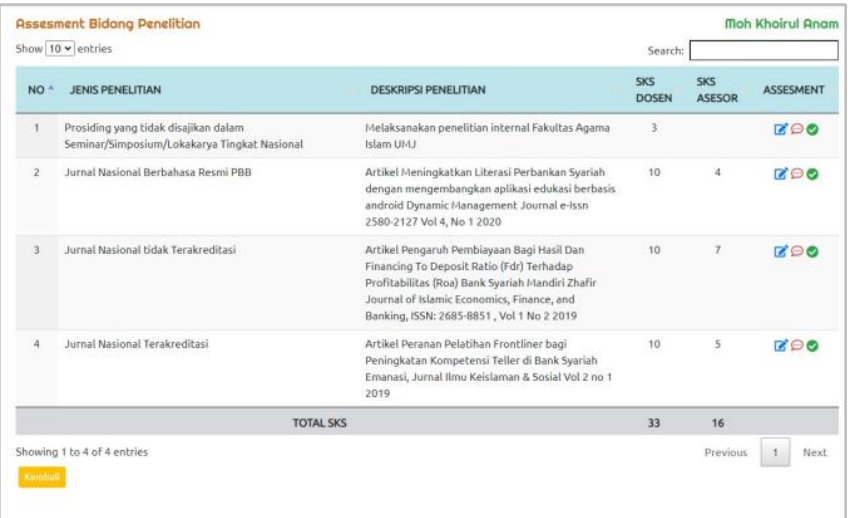

Gambar 13. Kegiatan Dosen Bidang Penelitian

Pada Gambar 13, terlihat daftar kegiatan dosen untuk bidang penelitian. Pada kolom Assesment terdapat icon untuk menilai dan memberi catatan jika diperlukan.

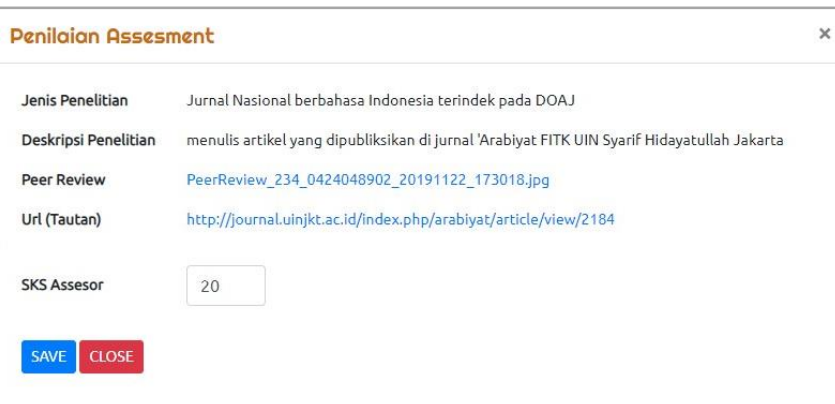

Gambar 14. Verifikasi bukti penelitian dan pemberian nilai

\section{Dashbaord Admin}

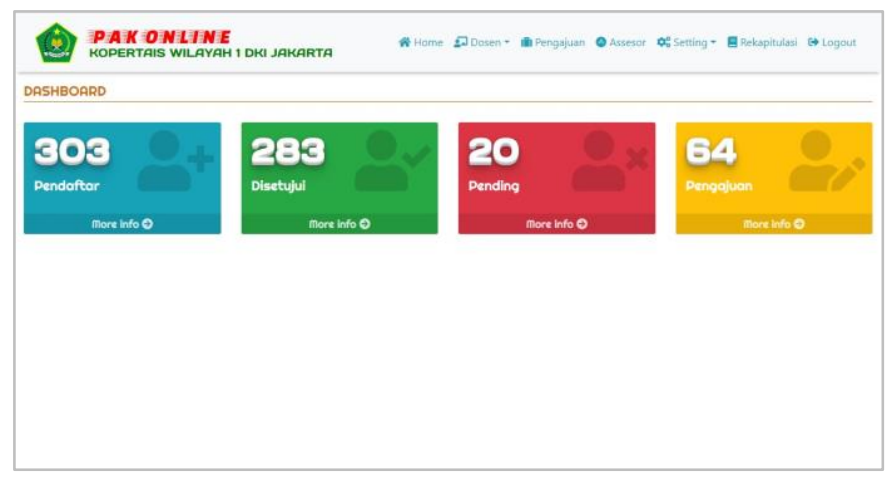

Gambar 15. Dashboard Admin

Pada Gambar 15. dashboard admin, terlihat rekapitulasi berapa dosen yang telah melakukan pendaftaran, sudah disetujui, belum disetujui, dan yang mengajukan kenaikan jafung.

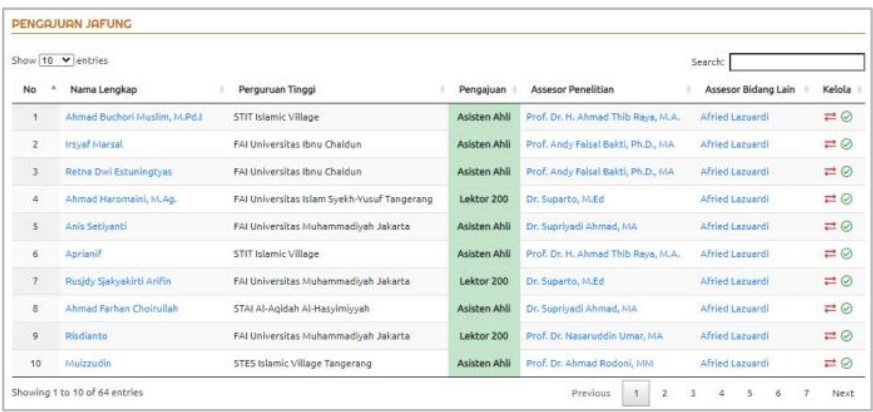

Gambar 15. Daftar yang mengajukan kenaikan Jafung

\section{Pengujian Sistem (Test)}

Setelah tahap pembuatan kode selesai, maka dilanjutkan dengan tahap pengujian sistem. Pengujian sistem dilakukan dengan tujuan untuk menjamin sistem yang dibangun sesuai dengan hasil analisa dan perancangan dan tidak menemukan masalah ketika diimplementasikan.

Adapun pengujian pada Sistem Informasi Penetapan Angka Kredit Dosen ini menggunakan dua pengujian, yaitu Black Box Testing dan User Acceptence Test (UAT).

Pengujian Black Box Testing dilakukan dengan teknik test cases pada semua use case yang ada pada sistem melalui tabel pengujian, mulai dari case Register, Login, hingga Logout. Dari pengujian ini menghasilkan semua proses berjalan dengan baik dengan status sukses.

Pengujian dengan metode UAT, dilakukan dengan tiga skenario, yaitu skenario level user admin, dosen, dan asesor. Pengujian ketiga level user dilaksanakan pada kegiatan sosialisasi yang diselenggarakan oleh Kopertais dalam waktu yang berbeda.

\section{1) Pengujian User Level Admin}

Berikut tabel skenario pengujian level Admin yang langsung diuji oleh Admin Kopertais.

Tabel 4.

Skenario Pengujian Level Admin

\begin{tabular}{|c|c|c|c|}
\hline No & Skenario Pengujian & Keterangan Hasil & $\begin{array}{l}\text { Hasil } \\
\text { Akhir }\end{array}$ \\
\hline 1. & $\begin{array}{l}\text { Admin melakukan login ke } \\
\text { sistem dengan memasukkan } \\
\text { username dan password }\end{array}$ & $\begin{array}{l}\text { Admin berhasil login ke } \\
\text { dashbard }\end{array}$ & Passed \\
\hline 2. & $\begin{array}{l}\text { Admin melakukan verifikasi } \\
\text { data pendafatran dosen dan } \\
\text { approval akun dosen }\end{array}$ & $\begin{array}{l}\text { Admin berhasil } \\
\text { melakukan verifikasi } \\
\text { data dan approval user }\end{array}$ & Passed \\
\hline 3. & $\begin{array}{l}\text { Admin melakukan setting } \\
\text { penjadwalan pengajuan } \\
\text { jafung dosen }\end{array}$ & $\begin{array}{l}\text { Admin berhasil } \\
\text { membuat jadwal di } \\
\text { sistem }\end{array}$ & Passed \\
\hline 4. & $\begin{array}{l}\text { Admin melakukan perubahan } \\
\text { jadwal pengajuan Jafung }\end{array}$ & $\begin{array}{l}\text { Admin berhasil } \\
\text { melakukan perubahan } \\
\text { jadwal }\end{array}$ & Passed \\
\hline 5. & $\begin{array}{l}\text { Admin melakukan edit } \\
\text { biodata dosen }\end{array}$ & $\begin{array}{l}\text { Admin berhasil } \\
\text { melakukan perbaikan } \\
\text { data dosn }\end{array}$ & Passed \\
\hline 6. & $\begin{array}{l}\text { Admin melakukan CRUD } \\
\text { (Create, Read, Update, } \\
\text { Delete) data PTKIS }\end{array}$ & $\begin{array}{l}\text { Admin berhasil } \\
\text { melakukan CRUD } \\
\text { PTKIS }\end{array}$ & Passed \\
\hline 7. & $\begin{array}{l}\text { Admin melakukan CRUD } \\
\text { (Create, Read, Update, } \\
\text { Delete) data Asesor }\end{array}$ & $\begin{array}{l}\text { Admin berhasil } \\
\text { melakukan CRUD } \\
\text { Asesor }\end{array}$ & Passed \\
\hline 8. & $\begin{array}{l}\text { Admin melakukan pembagian } \\
\text { assesment untuk assesor }\end{array}$ & $\begin{array}{l}\text { Admin berhasil } \\
\text { melakukan pembagian } \\
\text { dosen untuk assesment } \\
\text { asesor }\end{array}$ & Passed \\
\hline 9. & Admin melakukan monitoring & Admin berhasil melihat & Passed \\
\hline
\end{tabular}




\begin{tabular}{|c|c|c|c|}
\hline & $\begin{array}{l}\text { proses penilaian jafung oleh } \\
\text { Assesor }\end{array}$ & $\begin{array}{l}\text { status penilaian Jafung } \\
\text { oleh assesor }\end{array}$ & \\
\hline 10. & $\begin{array}{l}\text { Admin mengakses } \\
\text { rekapitulasi pengajuan jafung }\end{array}$ & $\begin{array}{l}\text { Admin berhasil melihat } \\
\text { rekapitulasi pengajuan } \\
\text { Jafung dosen }\end{array}$ & Passed \\
\hline 11. & $\begin{array}{l}\text { Admin melakukan pencetakan } \\
\text { Penetapan Angka Kredit } \\
\text { (PAK) Dosen }\end{array}$ & $\begin{array}{l}\text { Admin berhasil } \\
\text { melakukan pencetakan } \\
\text { Penetapan Angka Kredit } \\
\text { (PAK) Dosen }\end{array}$ & Passed \\
\hline 12. & $\begin{array}{l}\text { Admin melakukan perubahan } \\
\text { password }\end{array}$ & $\begin{array}{l}\text { Admin berhasil } \\
\text { melakukan perubahan } \\
\text { password }\end{array}$ & Passed \\
\hline 13. & $\begin{array}{l}\text { Admin melakukan proses } \\
\text { Logout }\end{array}$ & $\begin{array}{l}\text { Admin berhasil keluar } \\
\text { dari sistem PAK Online }\end{array}$ & Passed \\
\hline
\end{tabular}

2) Pengujian User Level Dosen

Tabel 5.

Skenario Pengujian Level Dosen

\begin{tabular}{|c|c|c|c|}
\hline No & Skenario Pengujian & Keterangan Hasil & $\begin{array}{l}\text { Hasil } \\
\text { Akhir }\end{array}$ \\
\hline 1. & $\begin{array}{l}\text { Dosen melakukan } \\
\text { registrasi ke sistem }\end{array}$ & $\begin{array}{l}\text { Dosen berhasil } \\
\text { melakukan } \\
\text { pendaftaran }\end{array}$ & Passed \\
\hline 2. & $\begin{array}{l}\text { Dosen melakukan } \\
\text { login ke sistem dengan } \\
\text { memasukkan } \\
\text { username dan } \\
\text { password }\end{array}$ & $\begin{array}{l}\text { Dosen berhasil login } \\
\text { ke dashbard }\end{array}$ & Passed \\
\hline 3. & $\begin{array}{l}\text { Dosen melakukan } \\
\text { update biodata }\end{array}$ & $\begin{array}{l}\text { Dosen berhasil } \\
\text { melakukan perubahan } \\
\text { biodata }\end{array}$ & Passed \\
\hline 4. & $\begin{array}{l}\text { Dosen melakukan } \\
\text { upload dokumen } \\
\text { persyaratan }\end{array}$ & $\begin{array}{l}\text { Dosen berhasil } \\
\text { melakukan upload } \\
\text { dokumen persyaratan }\end{array}$ & Passed \\
\hline 5. & $\begin{array}{l}\text { Dosen melakukan } \\
\text { input laporan Bidang } \\
\text { Pengajaran }\end{array}$ & $\begin{array}{l}\text { Dosen berhasil input } \\
\text { laporan Bidang } \\
\text { Pengajaran }\end{array}$ & Passed \\
\hline 6. & $\begin{array}{l}\text { Dosen melakukan } \\
\text { input laporan Bidang } \\
\text { Penelitian }\end{array}$ & $\begin{array}{l}\text { Dosen berhasil input } \\
\text { laporan Bidang } \\
\text { Penelitian }\end{array}$ & Passed \\
\hline 7. & $\begin{array}{l}\text { Dosen melakukan } \\
\text { input laporan Bidang } \\
\text { Pengabdian Kepada } \\
\text { Masyarakat }\end{array}$ & $\begin{array}{l}\text { Dosen berhasil input } \\
\text { laporan Bidang } \\
\text { Pengabdian Kepada } \\
\text { Masyarakat }\end{array}$ & Passed \\
\hline 8. & $\begin{array}{l}\text { Dosen melakukan } \\
\text { input laporan Bidang } \\
\text { Penunjang Lainnya }\end{array}$ & $\begin{array}{l}\text { Dosen berhasil input } \\
\text { laporan Bidang } \\
\text { Penunjang Lainnya }\end{array}$ & Passed \\
\hline 9. & $\begin{array}{l}\text { Dosen mengakses } \\
\text { halaman rekapitulasi }\end{array}$ & $\begin{array}{l}\text { Dosen berhasil } \\
\text { mengakses halaman } \\
\text { rekapitulasi }\end{array}$ & Passed \\
\hline 10. & $\begin{array}{l}\text { Dosen memperbaiki } \\
\text { dokumen persyaratan }\end{array}$ & $\begin{array}{l}\text { Dosen berhasil } \\
\text { memperbaiki dokumen } \\
\text { persyaratan }\end{array}$ & Passed \\
\hline 11. & $\begin{array}{l}\text { Dosen memperbaiki } \\
\text { dokumen Bidang } \\
\text { Pengajaran }\end{array}$ & $\begin{array}{l}\text { Dosen berhasil } \\
\text { memperbaiki dokumen } \\
\text { Bidang Pengajaran }\end{array}$ & Passed \\
\hline 12. & $\begin{array}{l}\text { Dosen memperbaiki } \\
\text { dokumen Bidang } \\
\text { Penelitian }\end{array}$ & $\begin{array}{l}\text { Dosen berhasil } \\
\text { memperbaiki dokumen } \\
\text { Bidang Penelitian }\end{array}$ & Passed \\
\hline 13. & $\begin{array}{l}\text { Dosen memperbaiki } \\
\text { dokumen Bidang } \\
\text { Pengabdian Kepada } \\
\text { Masyarakat }\end{array}$ & $\begin{array}{l}\text { Dosen berhasil } \\
\text { memperbaiki dokumen } \\
\text { Bidang Pengabdian } \\
\text { Kepada Masyarakat }\end{array}$ & Passed \\
\hline 14. & $\begin{array}{l}\text { Dosen memperbaiki } \\
\text { dokumen Bidang } \\
\text { Penunjang Lainnya }\end{array}$ & $\begin{array}{l}\text { Dosen berhasil } \\
\text { memperbaiki dokumen } \\
\text { Bidang Penunjang } \\
\text { Lainnya }\end{array}$ & Passed \\
\hline 15. & $\begin{array}{l}\text { Dosen melakukan } \\
\text { pengajuan Jafung ke }\end{array}$ & $\begin{array}{l}\text { Dosen berhasil } \\
\text { melakukan pengajuan }\end{array}$ & Passed \\
\hline
\end{tabular}

\begin{tabular}{|llll}
\hline Assisten Ahli & $\begin{array}{l}\text { Jafung ke Assisten } \\
\text { Ahli }\end{array}$ & \\
\hline 16. & $\begin{array}{l}\text { Dosen melakukan } \\
\text { pengajuan Jafung ke } \\
\text { Lektor 200 }\end{array}$ & $\begin{array}{l}\text { Dosen berhasil } \\
\text { melakukan pengajuan } \\
\text { Jafung ke Lektor 200 }\end{array}$ & Passed \\
\hline 17. & $\begin{array}{l}\text { Dosen melakukan } \\
\text { pengajuan Jafung ke } \\
\text { Lektor 300 }\end{array}$ & $\begin{array}{l}\text { Dosen berhasil } \\
\text { melakukan pengajuan }\end{array}$ & Passed \\
Jafung ke Lektor 300 & \\
\hline 18. & $\begin{array}{l}\text { Dosen melakukan } \\
\text { proses Logout }\end{array}$ & $\begin{array}{l}\text { Dosen berhasil keluar } \\
\text { dari sistem PAK } \\
\text { Online }\end{array}$ & Passed \\
\hline \hline
\end{tabular}

\section{3) Pengujian User Level Assesor}

Tabel 6.

Skenario Pengujian Level Assesor

\begin{tabular}{|c|c|c|c|}
\hline No & Skenario Pengujian & Keterangan Hasil & $\begin{array}{l}\text { Hasil } \\
\text { Akhir }\end{array}$ \\
\hline 1. & $\begin{array}{l}\text { Assesor melakukan login } \\
\text { ke sistem dengan } \\
\text { memasukkan username } \\
\text { dan password }\end{array}$ & $\begin{array}{l}\text { Assesor berhasil login } \\
\text { ke dashbard }\end{array}$ & Passed \\
\hline 2. & $\begin{array}{l}\text { Assesor mengakses } \\
\text { halaman daftar assesment }\end{array}$ & $\begin{array}{l}\text { Assesor berhasil } \\
\text { mengakses halaman } \\
\text { daftar assesment }\end{array}$ & Passed \\
\hline 3. & $\begin{array}{l}\text { Assesor melakukan } \\
\text { verifikasi dokumen } \\
\text { persyaratan }\end{array}$ & $\begin{array}{l}\text { Assesor berhasil } \\
\text { melakukan verifikasi } \\
\text { dokumen persyaratan }\end{array}$ & Passed \\
\hline 4. & $\begin{array}{l}\text { Assesor melakukan } \\
\text { penilaian dokumen bidang } \\
\text { Pengajaran }\end{array}$ & $\begin{array}{l}\text { Assesor berhasil } \\
\text { melakukan penilaian } \\
\text { dokumen bidang } \\
\text { Pengajaran }\end{array}$ & Passed \\
\hline 5. & $\begin{array}{l}\text { Assesor melakukan } \\
\text { penilaian dokumen bidang } \\
\text { Penelitian }\end{array}$ & $\begin{array}{l}\text { Assesor berhasil } \\
\text { melakukan penilaian } \\
\text { dokumen bidang } \\
\text { Penelitian }\end{array}$ & Passed \\
\hline 6. & $\begin{array}{l}\text { Assesor melakukan } \\
\text { penilaian dokumen bidang } \\
\text { Pengabdian kepada } \\
\text { Masyarakat }\end{array}$ & $\begin{array}{l}\text { Assesor berhasil } \\
\text { melakukan penilaian } \\
\text { dokumen bidang } \\
\text { Pengabdian kepada } \\
\text { Masyarakat }\end{array}$ & Passed \\
\hline 7. & $\begin{array}{l}\text { Assesor melakukan } \\
\text { penilaian dokumen bidang } \\
\text { Penunjang Lainnya }\end{array}$ & $\begin{array}{l}\text { Assesor berhasil } \\
\text { melakukan penilaian } \\
\text { dokumen bidang } \\
\text { Penunjang Lainnya }\end{array}$ & Passed \\
\hline 8. & $\begin{array}{l}\text { Assesor mengakses } \\
\text { rekapitulasi penilaian }\end{array}$ & $\begin{array}{l}\text { Assesor berhasil } \\
\text { mengakses rekapitulasi } \\
\text { penilaian }\end{array}$ & Passed \\
\hline 9. & $\begin{array}{l}\text { Assesor melakukan proses } \\
\text { Logout }\end{array}$ & $\begin{array}{l}\text { Assesor berhasil keluar } \\
\text { dari sistem PAK Online }\end{array}$ & Passed \\
\hline
\end{tabular}

\section{KESIMPULAN}

Berdasarkan pembahasan yang sudah diuraikan di atas, maka dapat ditarik kesimpulan bahwa pengembangan Sistem Informasi Penialaian Angka Kredit Dosen (PAK Online) ini sudah berjalan sebagaimana mestinya, sesuai dengan analisis dan perancangan sistem dengan model Waterfall. PAK Online dapat diimplementasikan dengan baik, tanpa ada permasalahan yang berarti, dibuktikan dengan hasil pengujian melalui metode Black Box Testing dan User Acceptence Test (UAT).

Para dosen PTKIS yang di bawah koordinasi Kopertais 1 Wilayah DKI Jakarta dapat mengurus kenaikan jabatan fungisional secara online, sehingga prosesnya lebih efektif dan efisien. Dosen tidak perlu membawa dokumen ke PTKIS dan Kopertais. Assesor dapat menilai angka kredit dosen di mana 
saja dan kapan saja. Dengan sistem ini dimungkinkan komunikasi dua arah antara dosen dan assesor terkait perbaikan atau kekurangan dokumen.

Sistem penghitungan angka kredit dosen ini mengikuti Pedoman Operasional Penilaian Angka Kredit Kenaikan Pangkat/Jabatan Akademik Dosen Tahun 2019 yang dikeluarkan oleh Direktorat Jenderal Pendidikan Tinggi Kementerian Pendidikan dan Kebudayaan, sehingga dapat diterapkan juga pada Kopertais atau Kopertis lainnya, serta pada perguruan tinggi baik negeri maupun swasta.

\section{REFERENSI}

[1] L. E. Nugroho, "Kerangka Pengembangan Pendidikan Tinggi di Indonesia," pp. 112-113, 2013, [Online].

[2] B. Humas, "Kebijakan Pemanfaatan Teknologi Informasi di Kementerian Agama," no. 3, 2017, [Online].

[3] Pendis Kemenag RI, "Statistik PTKIS Kopertais Wilayah I DKI Jakarta," 2012. [Online].

[4] A. Sulhi, "Implementasi Pengembangan Sistem Laporan BKD (Studi Kasus BKD Online Kopertais Wilayah I DKI Jakarta)," KORDINAT, vol. XVII, pp. 419-432, 2018, [Online].

[5] E. Lestari, R. I. Heroza, and I. Zubiah, "Pengembangan Sistem Penilaian Angka Kredit Untuk Kenaikan Jabatan Akademik Dosen pada Jurusan Sistem Informasi Fakultas Ilmu Komputer Universitas Sriwijaya," 2016, pp. 145-161, [Online].

[6] B. Arie Minartiningtyas and I. K. Adi Sumariata, "Rancang Bangun
Sistem Informasi Perhitungan Angka Kredit Dosen STMIK STIKOM Indonesia," SINTECH (Science Inf. Technol. J., vol. 1, no. 1, pp. 41-50, Apr. 2018, doi: 10.31598/sintechjournal.v1i1.239.

[7] A. Agasi and A. Hadi, "Perancangan Sistem Informasi Kenaikan Jabatan Fungsional Dosen Dengan Framework Laravel Berbasis Web," J. Vokasional Tek. Elektron. dan Inform., vol. 6, no. 2, 2018.

[8] D. DIKTI, "Pedoman Angka Kredit Dosen 2019," 2019. [Online]..

[9] R. S. Pressman, Software Engineering A Practitioner's Approach, Fifth Edit. McGraw-Hill Higher Education, 2001.

[10] J. Osis and U. Donins, Unified Modeling Language. 2017.

[11] S. Nidhra, "Black Box and White Box Testing Techniques - A Literature Review," Int. J. Embed. Syst. Appl., vol. 2, no. 2, pp. 29-50, 2012, doi: 10.5121/ijesa.2012.2204.

[12] J. Frantiska, Visualization Tools for Learning Environment Development. 2018.

[13] G. Booch, "The unified modeling language," Perform. Comput. Rev., vol. 14, no. 13 , pp. 41-48, 1996, doi: 10.1016/B978-0-12-3820204.00003-3.

[14] S. Sinha, Beginning Laravel. 2019. 